\title{
Advances in Chemical Composition and Biological Activity of Mexican Propolis
}

\author{
Granados Pineda Jessica and Pérez Rojas Jazmin $\mathbf{M}^{*}$ \\ Subdirección de Investigación Básica, Instituto Nacional de Cancerología, Mexico
}

*Corresponding author: Jazmin M Pérez Rojas, Subdirección de Investigación Básica, Instituto Nacional de Cancerología, 14080 Mexico city, Mexico

\begin{abstract}
Propolis is a product created by honeybees from vegetal sources. Nowadays it is considered a medicinally or functional food because of the phytochemicals contained in it. Numerous papers have been published reporting the chemical composition of different countries around the globe due to its highly variability(phenolic compounds, sugars, terpenoids). Due to the variability in its chemical composition, various biological activities have been reported, among them are anti-inflammatory, antimicrobial, anticarcinogenic, among other. In Mexico has history on beekeeping that was modified by the Spanish conquest but endures to these days. Therefore, it is important to exploit the characteristics of the propolis of our region in order to know both their composition and beneficial properties.
\end{abstract}

Keywords: Propolis; Honeybees; Flavonoids

\section{Introduction}

Propolis is resinous material produced by honeybees, which collect secretions from plants organs and then they are mixed with beeswax and salivary enzymes [1]. Propolis color may vary from light yellow to dark brown [2]. Bees produce propolis to fill cracks in the hive, to regulate the temperature and embalm invaders [3]. The general composition comprises resins (50\%), waxes (30\%), essential oils (10\%) pollen (5\%) and other organic compounds (5\%) [4]. Some compounds reported in the resin are phenolics, esters, flavonoids, aldehydes and alcohols. This natural product has attracted the attention of researchers because of its biological activity and the diversity of its composition. Since 1970's, scientists around the world have reported the chemical composition and biological composition of propolis from different countries such as Czeck Republic, Bulgaria, Croatia, Portugal, China, Netherlands, Italy, France and Brazil, among others. However, in Mexico little has been explored of the propolis of this region despite that apiculture has been an ancient activity. Pre-Colombian cultures raised stingless bees for food, medicinal and religious purposes. In the tropical region of Mexico, Mayans bred honeybees such as Melipona beechii, Melipona domestica, Melipona fulvipes and Trigona sp, in order to collect honey and wax [5]. Spanish conquerors brought with them the European bee, Apis mellifera, who partially replaced the native Mexican bees in recollection of bee products. Nowadays, Apis mellifera is the main honeybee exploited in Mexico for honey, beeswax, pollen, royal jelly and propolis. Propolis is considered only a side product derived from the hive, therefore there is no reliable source to measure the production of Mexican propolis [6]. However, it is known that the Peninsula of Yucatan has been the most productive from 2000 to 2012, in terms of honey production [7]. Propolis is commercialized in Mexico in regional markets and local producers in its raw form, but mainly it is combined with honey to make hard candies or hydroalcoholic solutions (Figure 1). The quality of propolis or propolis products is dictated by Mexican regulation NOM-003-SAG/GAN-2017 "Propóleos, producción y especificaciones para su procesamiento". This normative comprises a qualitative test of flavonoids and phenolics, oxidation index, 
quantification of phenolics, quantification of flavonoids, antioxidant activity (DPPH bleaching assay) and antimicrobial activity on three bacteria. It is worthy to mention that before the NOM-003-SAG/ GAN-2017, there was no regulation to ensure the quality of propolis.

\section{Chemical Composition}

Research on propolis has revealed over 500 constituents: phenolic compounds, fatty acids, sugars, minerals and terpenoids [8-11]. It is known that propolis composition varies greatly depending on the geographical origin, the botanical source, the time and method of harvest and solvent used in extraction [12-13]. The Ministry of Agriculture and Rural Development has divided Mexico into five beekeeping areas, in accordance to the honey production and geographical distribution: Altiplano, Pacific Coast, Gulf, North and Peninsula of Yucatan [14]. We can assume that propolis composition would have a pattern for each region as honey does. To date, there are reports of composition from the North $(A, B, C, D$, E, F and G), Altipano (H), Gulf (I), Pacific Coast (J), and Peninsula of Yucatan (K, L, M and N) (Figure 2).

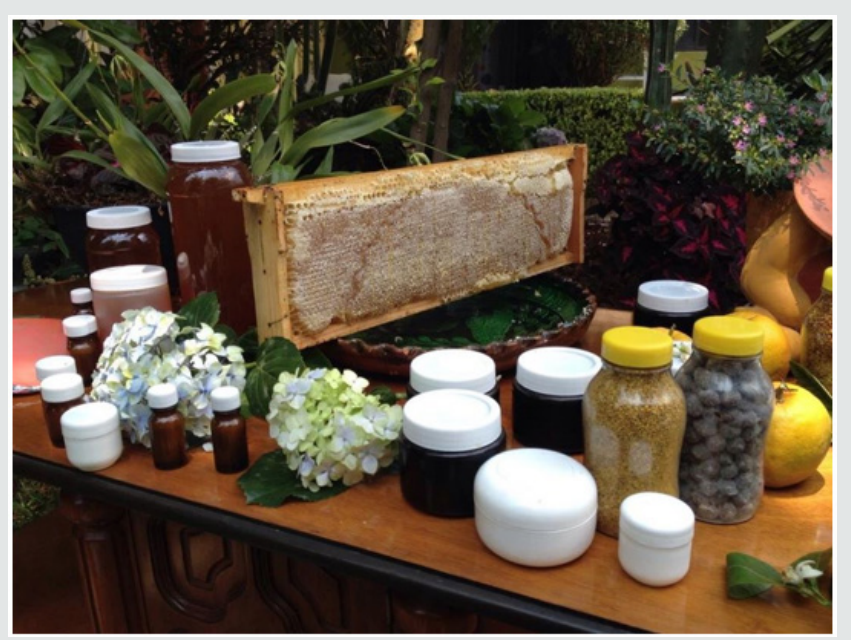

Figure 1: Honeybee products traded in a local market in Milpa Alta, Mexico City. Photo by Mielin: https:/ / www.facebook.com/mielin803/photos/a.834946096589119/834946309922431/?type=3\&theater.

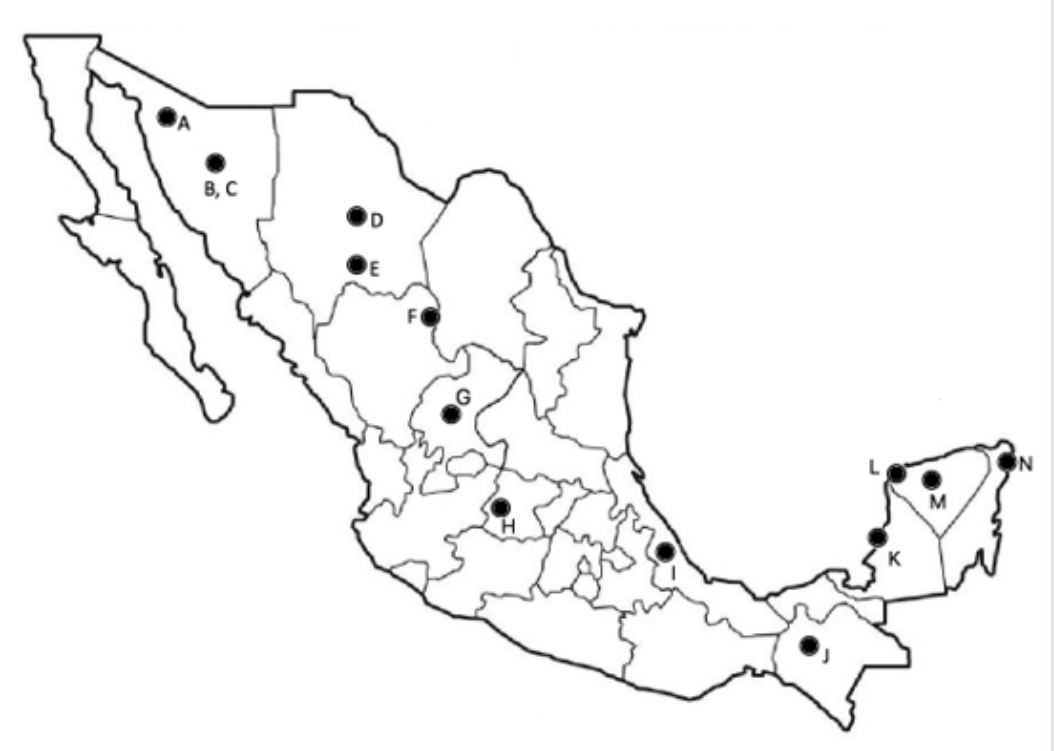

Figure 2: Sites of collection of propolis from provinces of Mexico.

A, Caborca, Sonora; B, Ures, Sonora; C, Pueblo de Alamos, Sonora; D, Aquiles Serdan, Chihuahua; E, Parral, Chihuahua; F, Gomez Palacio, Durango; G, Fresnillo, Zacatecas; H, Silao, Guanajuato; I, Coatepec, Veracruz; J, San Cristobal de las Casas, Chiapas; K, Champoton, Campeche; L, Hunucma, Yucatan; M, Mani, Yucatan; N, Solaridad, Quintana Roo. 


\section{Phenolics and Phenolic Esters}

Phenolics are natural constituents of plants that are characterized by the presence of hydroxy substituents in their structures. Together with total flavonoid content, phenolics content in propolis is another quality characteristic in Mexican regulation NOM-003-SAG/GAN-2017, which minimum content must be $5 \%$ w/w. Only samples from Caborca, Ures, Pueblo de Alamos, Aquiles Serdan, Parral, Gomez Palacio, Fresnillo, Silao and Solidaridad were studied for phenolic content, from which the Solidaridad sample did not fulfilled the Mexican regulation. Sample from Solidaridad showed no content of phenolics since the major compounds were terpenoids. Argentinean and French propolis possess similar phenolic content [15-16].

\section{Flavonoids}

Table 1: Flavonoids and phenolics isolated from Sonora propolis and tested for antiproliferative activity.

\begin{tabular}{|c|c|}
\hline & Compound \\
\hline 1 & Chrysin \\
\hline 2 & $\begin{array}{l}\left(7^{\prime \prime} \mathrm{R}\right)-8-\left[1-\left(4^{\prime} \text {-hydroxy-3'-methoxyphenyl) }\right.\right. \\
\text { chrysin }\end{array}$ \\
\hline 5 & 4',5,7-trihydroxy-3,3'- dimethoxyflavone \\
\hline 7 & Apigenin \\
\hline 13 & Pinocembrin \\
\hline 14 & $\begin{array}{l}(2 \mathrm{R}, 3 \mathrm{R})-3,5 \text {-dihydroxy-7-methoxyflavanone } \\
\text { butyrate }\end{array}$ \\
\hline 22 & $\begin{array}{l}(2 \mathrm{R}, 3 \mathrm{~S})-8 \text { - }[4-\text { phenylprop-2-en-1-one]-4',7-dihydroxy-3',5- } \\
\text { dimethoxyflavan-3-ol }\end{array}$ \\
\hline 23 & Galangin \\
\hline 31 & $\begin{array}{l}\left(7^{\prime \prime} \mathrm{R}\right)-8-\left[1-\left(4^{\prime} \text {-hydroxy-3'-methoxyphenyl) }\right.\right. \\
\text { galangin }\end{array}$ \\
\hline 36 & Alpinone \\
\hline 37 & $(2 \mathrm{R}, 3 \mathrm{R})$-alpinone-3-acetate \\
\hline 40 & Pinobanksin-3-0-acetate \\
\hline 43 & Pinobanksin-3-0-propanoate \\
\hline 47 & Pinobanksin-3-0-isobutyrate \\
\hline 63 & Benzyl (E)-3,4-dimethoxycinnamate \\
\hline 65 & 3,3-dimethylallyl (E)-ferulate \\
\hline 66 & Isopent-3-enyl (E)-ferulate \\
\hline 67 & Benzyl (E)-ferulate \\
\hline 68 & (E)-cinnamyl (E)-isoferulate \\
\hline 72 & Benzyl (E)-p-coumarate \\
\hline 75 & (E)-ferulic acid \\
\hline 76 & (E)-cinnamyl (E)-p-coumarate \\
\hline 81 & 2-acetyl-1,3-di-(E)-feruloylglycerol \\
\hline 82 & (E)-p-coumaric acid \\
\hline
\end{tabular}

Flavonoids are the most reported compounds in propolis around the world. The content of flavonoids is considered to reflect the quality of the propolis, as the Mexican regulation NOM-
003-SAG/GAN-2017 stablishes the requirement of minimum of $0.5 \% \mathrm{w} / \mathrm{w}$ of flavonoids. However, only samples collected in the regions Aquiles Serdan, Parral, Gomez Palacio, Fresnillo and Silao were assessed for this parameter and found to fulfill the content of flavonoids. Table 1 depicts the types of flavonoids isolated from the propolis samples. Pinocembrin was the most reported compound in Mexican propolis, in ten out of fourteen samples, followed by Chrysin in six out of fourteen samples. Both flavonoids, together with galangin, kaempferol, rhamnetin and epoxypinocembrin chalcone, have been identified in poplar bud exudates [17]. In fact, pinocembrin is considered the marker of poplar propolis [18], therefore it is found in propolis from Spain, France, China, Portugal, Rumania, Croatia, Turkey, New Zealand, Poland, Argentina [12,1927].

\section{Pterocarpans}

The major components of South American red propolis (eg. Cuba and Brazil) are isoflavans, isoflavons and pterocarpans [28]. The sample of the region Champoton turned to be the only one containing pterocarpans and isoflavonoids, hence it could be excluded from the classification of poplar type and considered as red propolis.

\section{Triterpenoids}

Triterpenoids are natural occurring compounds in plants, which have anti-inflammatory, hepatoprotective, analgesic, immunomodulatory, antimicrobial, antimycotic, virostatic, and tonic effects [29]. Hunucma and Solidaridad samples contained exclusively triterpenes, this fact excludes them from the poplar type, red type or any other, since there is no type of propolis defined solely on triterpenes. However, the high content of triterpenes has been found in propolis from Ethiopia, being $\alpha$ - and $\beta$-amyrins and amyryl acetates the major compounds [30]. It is also similar to geopropolis from Mani (See Section Geopropolis). Botanical origin Depending on the ecosystem, honeybees will collect resins from different source plants, choosing appropriate representatives of the local flora [31].

Salatino and coworkers [18] made a classification of propolis, according to its geographic zone, chemical composition and botanical source reported in literature, into five types: I, from Populus section Aigeiros; II, from Baccharis dracunculifolia; III, from Clusia; IV, from Macaranga and V, Cupressaceae. According to this classification, Mexican propolis belongs to type I propolis, the temperate poplar propolis. Bees seem to gather the resins from Populus species and their hybrids. As for the tropical regions, the plant sources are rich of prenylated benzophenones, diterpenes and flavonoids [4]. As mentioned before, Mexican propolis falls into the classification of poplar type or type I. However, this is true for samples North, Pacific Coast and Gulf, since Pinocembrin and 
other flavonoids and phenolics were found as major constituents. The most common source from these compounds is the Populus genus, in fact the composition of Populus bud exudates have been studied to corroborate the botanical origin [17]. In Mexico is not well reported the species and abundance of Populus present throughout the country. Nevertheless, it is known that flavonoids such as pinocembrin, pinobanksin 3-acetate, tectochrysin, galangin, and chrysin have been found in Populus nigra [28]. Secondary sources visited by Apis mellifera are birch, alder, oak, pine and hazel. The southeast region of Mexico has tropical weather which is directly reflected on the chemical composition of propolis. Champoton, Hunucma, Mani and Solidaridad samples have a different composition from the rest of the country (See Section Chemical Composition), since these regions are considered to have a tropical weather. In tropical or subtropical areas, poplar trees are scarce, as a result, bees visit another type of trees. Two potential sources used by the bees for their production of propolis in Yucatan and Quintana Roo are Bursera simaruba and Lysiloma latisiliquum $[20,32]$. Dalbergia is another probable source of resin material in this region, because some compounds isolated from these samples (eg. (-)-Mucronulatol, (+)-Vestitol and (-)-Melilotocarpan A) are related to Dalbergia exudates and Caribbean and Brazilian propolis.

\section{Biological Activity}

Poplar type propolis is characterized by flavonoids, phenolic acids and their esters as bioactive constituents [28]. Particularly, flavonoids are associated to a broad spectrum of health effects because if their antioxidant, anti-inflammatory, anti-mutagenic, antimicrobial, anticarcinogenic and vascular activities [33].

\section{Anticancer}

Silao extract showed an inhibition of proliferation of rat C6 glioma cell line comparable to temozolamide, on the other hand, it did not efficiently inhibit human cervical cancer cell lines (HeLa, $\mathrm{SiHa}$, and CaSki) proliferation compared to cisplatin [34]. Alday and coworkers [35] tested the antiproliferative activity of the methanolic extract of Sonora and the flavonoids isolated from it, on B cell lymphoma cell line M12.C3.F6. The methanolic extract exhibited an inhibitory concentration $\left(\mathrm{IC}_{50}\right.$ ) of $20.6 \pm 0.5 \mu \mathrm{g} / \mathrm{mL}$, while the $\mathrm{IC}_{50}$ of the flavonoids pinobanksin-3-0-propanoate, pinobanksin3-0-butyrate, pinobanksin-3-0-pentanoate, pinobanksin, CAPE, galangin, chrysin ranged from $17.3 \mu \mathrm{M}$ to $76.6 \mu \mathrm{M}$. Moreover, the extract showed to induce apoptosis through loss of mitochondrial membrane potential and activation of caspase 3, 8 and 9. Flavonoids and phenolics listed in Table 1 were isolated. These compounds were evaluated for the preferential cytotoxicity on PANC-1 human pancreatic cancer cells, cytotoxicity was expressed as $\mathrm{PC}_{50}[36]$. The $\mathrm{PC}_{50}$ ranged from 4.6 to $98.9 \mu \mathrm{M}$, showing a great potential for antiproliferative activity.
Hernandez and coworkers [37] tested the antiproliferative effect of Caborca, Ures and Pueblo de Alamos samples on human lung carcinoma A-549, human colonic adenocarcinoma LS 180, human cervix carcinoma HeLa , normal subcutaneous connective tissue NCTC clone L 929, murine B-cell lymphoma M12.C3.F6 and macrophage, Abelson murine leukemia virus transformed RAW. The components of propolis chrysin, xanthomicrol, acacetin, pinocembrin, naringenin, hesperetin, rutin, pinobanksin-3-acetate and CAPE, were tested as well. Pueblo de Alamos extract showed the best antiproliferative activity in all the cell lines tested in a range of 0.8 to $53.6(\mu \mathrm{g} / \mathrm{mL})$. Only CAPE, galangin, chrysin and xanthomicrol showed antiproliferative activity on most of the line cells $\left(\mathrm{IC}_{50} 3.2\right.$ 95.4 $\mu \mathrm{M}$ ), mainly on L-929, M12.C3.F6, RAW and, HeLa. These flavonoids could be partially responsible for the antiproliferative activity of propolis extracts. Flavonoids can exert anticancer effect through various mechanisms such as inactivation of oxygen radicals (antioxidative), binding to electrophiles, induction of phase 2 detoxification enzymes, increase in apoptosis, inhibition of cell proliferation and inhibition of lipid peroxidation [38].

\section{Anti-Inflammatory}

Chiapas (J) extract showed anti-inflammatory activity comparable to indomethacin $\left(\mathrm{IC}_{50} 1.21\right.$ and $0.84 \mathrm{mg} / \mathrm{ear}$, respectively) in the model of ear edema in mice by 12-0-tetradecanoylphorbol-13-acetate. Besides diminishing histologic signs of inflammation, J decreased the activity of myeloperoxidase [39]. The flavonoids pinostrobin, izalpinin, cinnamic acid, kaempferol, 3,3-dimethylallyl caffeate, isopent-3-enyl caffeate, 3,4-dimethoxycinnamic acid and rhamnetin did not show antiinflammatory activity. Whereas pinocembrin had comparable effect to celecoxib $\left(\mathrm{IC}_{50} 2.53 \mu \mathrm{mol} / \mathrm{ear}\right.$ and $\mathrm{IC}_{50} 0.91 \mu \mathrm{mol} / \mathrm{ear}$, respectively) and to indomethacin $(91.09 \pm 3.66 \%$ inhibition and $91.09 .09 \pm 0.006 \%$, respectively). The authors attribute to pinocembrin the anti-inflammatory effect observed in the propolis extract because of its high myeloperoxidase inhibition. Research on pinocembrin has revealed that it downregulates TNF- $\alpha$, IL-1 $\beta$, and IL-6, also suppresses IкB $\alpha$, JNK and, p38MAPK [40]; which are some mechanisms that additionally explain the anti-inflammatory effect.

\section{Antidiabetic}

Chihuahua (D) propolis extract administered to streptozotocin induced diabetic mice reduces blood glucose levels and increases serum insulin levels. The pancreatic islets were found to contain insulin in contrast to the diabetic controls. There was found that the activity of antioxidant enzymes superoxide dismutase, catalase and glutathione peroxidase were restored in the treated mice in compare to non-treated mice [41]. The observed hypoglycemic activity could be the result of the secretagogue and antioxidant effects of the extract. Pinocembrin has a potential therapeutic use in 
diabetic nephropathy, a chronic complication of diabetes mellitus. When pinocembrin was administered to streptozotocin-induced hyperglycemic rats, before diabetic nephropathy establishment, it was able to improve survival and, to partially decrease blood glucose, lipids and renal function. These results correlated with a decrease in oxidative stress. However, when pinocembrin was administered once renal structural damage was stablished, pinocembrin improved triglycerides and LDL, but it worsens all renal function parameters due to increases ROS [42].

Iranian propolis has similar effects to Mexican propolis, on streptozotocin-induced hyperglycemic rats. The ethanolic extract of Iranian propolis avoided body weight loss and, high FBG and MDA content, as well as reducing GBM thickness and glomerular area. These results indicate that propolis protection was due to its antioxidants properties [43]. Various flavonoids have been studied for its antidiabetic properties. Naringenin has showed to inhibit of intestinal $\alpha$-glucosidase, to improve insulin sensitivity and glucose tolerance [44-45]. On the other hand, chrysin inhibits TNF- $\alpha$ pathway and downregulates the expression of TGF- $\beta$, fibronectin and collagen-IV proteins [46]. These flavonoids, reported to be present in Mexican propolis, with their aforementioned mechanisms and their known antioxidative activity, could explain the antidiabetic effect described for the Chihuahua propolis.

\section{Antimicrobial}

Ethanolic extract of Silao $(\mathrm{H})$ propolis and, the isolated flavonoids and phenolic acids were tested against oral pathogens Streptococcus mutans, Streptococcus oralis, Streptococcus sanguinis, and Phorphyromonas gingivalis. The inhibitory effect on the microorganisms ranged between $125-500 \mu \mathrm{g} / \mathrm{mL}$ for the propolis extract and $128-1024 \mu \mathrm{g} / \mathrm{mL}$ for the isolated compounds. Chiapas propolis (J) showed moderate inhibitory effect (MIC $=250 \mu \mathrm{g} / \mathrm{mL}$ ) on Mycobacterium tuberculosis H37Rv in the Resazurin Microtiter Assay [39]. Sonoran propolis (Caborca, Ures and Pueblo de Alamos) samples were investigated for the effect on clinical isolates of Staphylococcus aureus. Ures sample had the highest inhibitory activity (MIC $200 \mu \mathrm{g} / \mathrm{mL}$ ) while Pueblo de Alamos showed no activity [47]. These samples also inhibited the growth of various Vibrio species such as cholerae (serotypes Inaba, non-01, Ogawa), vulnificus, alginolyticus, fluvialis and parahemolyticus, in a range of $50-200 \mu \mathrm{g} / \mathrm{mL}$. Furthermore, propolis constituents were tested against $V$. cholerae, showing high (galangin and CAPE), moderate (pinocembrin, hesperetin and naringenin) and low (chrysin and acacetin) activity [48].

Quintero-Mora and coworkers [49] investigated the inhibitory activity on Candida albicans of various propolis from State of Mexico, Veracruz and Puebla not shown in Figure 2, fresh prepared and commercial extracts. The MIC was highly variable and ranged from 0.6 to $>10 \mathrm{mg} / \mathrm{mL}$. Recently Al-Ani et al. [50] tested propolis collected in Germany, Ireland and Czech Republic on Grampositive (Staphylococcus aureus, Staphylococcus saprophyticus, Staphylococcus epidermidis, MRSA/NCTC, VRE Van B, Streptococcus pyogenes, Streptococcus pneumoniae, Streptococcus oralis, Streptococcus agalactia, Streptococcus thermophilus, Bacillus subtilis, Enterococcus casseliflavus), Gram-negative bacteria (Klebsiella pneumoniae, Klebsiella oxytoca, Escherichia coli, Escherichia coli 0157:H7, Pseudomonas aeruginosa, Salmonella choleraesuis, Shigella flexneri, Haemophilus influenzae, Acinetobacter baumannii, Burkholderia cepacia, Enterobacter clacae, Yersinia enterocolitis) and fungi (Candida albicans, Candida glabrata, Candida parapsilosis, Candida tropicalis, Candida krusei). The MICs for Gram-positive bacteria ranged from $0.08 \mathrm{mg} / \mathrm{mL}$ to $5 \mathrm{mg} / \mathrm{mL} ; 0.6 \mathrm{mg} / \mathrm{mL}$ to $5 \mathrm{mg} /$ $\mathrm{mL}$ for Gram-negative and, $0.1 \mathrm{mg} / \mathrm{mL}-5 \mathrm{mg} / \mathrm{mL}$ for fungi. Thus, the European propolis showed higher inhibitory effect than that observed in Mexican propolis. Antimicrobial activity of propolis is attributed to the phenolic content and particularly, to the flavonoids galangin and pinocembrin [51]. The reported mechanisms are membrane damage, inhibition of acid nucleic synthesis, and inhibition of energy metabolism [52].

\section{Antiparasitic}

Sonoran propolis (Caborca, Ures and Pueblo de Alamos) samples were investigated for the effect on Giardia lamblia trophozoites. Ures sample showed the highest activity $\left(\mathrm{IC}_{50}=63.8 \mu \mathrm{g} / \mathrm{mL}\right.$ ), Pueblo de Alamos had low activity $\left(\mathrm{IC}_{50}=222 \mu \mathrm{g} / \mathrm{mL}\right.$ ) and Caborca did not show significant inhibition on the trophozoite growth. In the microscopic analysis of the trophozoites, there were morphological changes on the trophozoites treated with B compared to the control trophozoites, as well as cellular debris. The six main constituents of Sonoran propolis (CAPE, naringenin, hesperetin, pinocembrin, chrysin and, rutin) were tested on G. lamblia trophozoites, being CAPE the most active ( $\mathrm{IC}_{50} 63.1 \pm 0.9 \mu \mathrm{g} / \mathrm{mL}$ ) and, hesperetin ( $\mathrm{IC}_{50}$ $149.6 \pm 24.8 \mu \mathrm{g} / \mathrm{mL}$ ) and pinocembrin $\left(\mathrm{IC}_{50} 174.4 \pm 26.9 \mu \mathrm{g} / \mathrm{mL}\right)$ the weakest ones [53]. European propolis extracts collected in different regions of the United Kingdom, Bulgaria and Lithuania, showed activity against human and bee parasites. The extracts decreased the survival of wild-type and resistant strains of Leishmania mexicana with a $\mathrm{EC}_{50} \quad 0.1-5.67 \mu \mathrm{g} / \mathrm{mL}$ and $0.29-1.55 \mu \mathrm{g} / \mathrm{mL}$, respectively; wild-type and resistant strains of Trypanosoma brucei with a $\mathrm{EC}_{50} 3.67-18.4 \mu \mathrm{g} / \mathrm{mL}$ and $2.5-25.0 \mu \mathrm{g} / \mathrm{mL}$, respectively; Trypanosoma congolense with a $\mathrm{EC}_{50} 1.96-35.7 \mu \mathrm{g} / \mathrm{mL}$ and, Crithidia fasciculata with a $\mathrm{EC}_{50} 2.58-23.8 \mu \mathrm{g} / \mathrm{mL}$. Orthogonal partial least squares analysis of the propolis activity and the LC-MS profile, revealed that butyrate ester of pinobanksin is related to the high activity against Trypanosoma brucei, methyl esters of chrysin are related to high activity against Trypanosoma congolense, methyl esters of galangin and pinobanksin are related against Crithidia fasciculata, but no compounds were found to be related to the anti-Leishmanial activity [54]. The activity of Mexican propolis 
and European propolis may not be comparable since they inhibit different parasites, however, they both bring out the potential of temperate propolis and flavonoids against parasites.

\section{Geopropolis}

Stingless bees mix resinous material from plants, bees wax and soil to form geopropolis. This type of bees, also called Meliponinos, is present in all tropical zones over the world and around 400 to 500 species are known [55]. In Mexico 46 species have been identified, being Plebeia, Trigona, Melipona and Trigonisca the most diverse genera [56]. Stingless beekeeping was present in the cosmogony and mythology of Mesoamerican civilizations, as well as a source of staple food [57]. The most exploited species of Meliponinos, for their honey and wax, are Melipona beecheii in the Mayan area and Scaptotrigona mexicana in the Nahua area [56]. Despite the important historical background of stingless bees in Mexico, there is scant research on the propolis made by Meliponinos native to this country. The available research on geopropolis is from Brazil yet is not as abundant as the propolis research. Geopropolis differs from propolis because of the mineral and soil content, and the absence of plant trichomes of the former, despite of this, geopropolis has similar functions in the hive [58]. Biological activities reported for geopropolis are gastroprotective, antimicrobial, antioxidant, anticancer, anti-inflammatory, sedative, antimutagenic [59-63].

Regarding the chemical composition, polyphenols, phenolic acids, flavonoids, hydrolysable tannins, triterpenoids and, saponins [60,64-65]. Pentacyclic triterpenes were the main compounds identified in Melipona beecheii geopropolis from Mani (L), for instance lupenone, $\alpha$-amyrin and $\beta$-amyrin [66]. Volatile compounds comprise approximately $10 \%$ of the propolis constituents and they confer odor and pharmacological effects. Pino et al. [67] compared the volatile fraction of propolis from Apis mellifera and Melipona beecheii from Yucatan, they were able to establish characteristic compounds of each type of propolis. Honeybees propolis' exclusive volatiles were styrene, phenylacetaldehyde, trans-sabinene hydrate nonanal, decanal, 2-undecanone, cyperene, cis- $\alpha$-bergamotene, massoia lactone, ar-curcumene, cis-calamenene, cadina-1,4diene, $\alpha$-cadinene, $\beta$-eudesmol, $\alpha$-bisabolol, neryl linalool, geranyl linalool, manoyl oxide, kaur-16-ene, pentacosane and heptacosane. Stingless bees geopropolis' exclusive volatiles were santolinatriene, 6-methyl-5-hepten-2-one, $\alpha$-phellandrene, $\delta$-3-carene, p-menth1-ene, $p$-cymenene, $\alpha$-pinene oxide, chrysanthenone, trans-pmentha-2,8-dien-1-ol, cis-limonene oxide, verbenyl ethyl ether, germacrene A, $\alpha$-dehydro-ar-himachalene, $\beta$-vetivenene and humulene epoxide I. However, both samples had in common the compounds $\alpha$-pinene, $\beta$-pinene, trans-verbenol, $\alpha$-copaene, $\beta$-bourbonene, $\beta$-caryophyllene, spathulenol and caryophyllene oxide. Geopropolis from Coatepec, Veracruz was subjected to HS-SPME-GC-TOF-MS analysis to identify volatile components. The major compounds identified in the total current ion were $\beta$-fenchene, styrene, benzaldehyde, (Z)-ocimenone, $\alpha$-pinene, $\mathrm{m}$-cymene, trans-isocarveol, limonene and $\beta$-pinene [68].

\section{Conclusion}

The chemical composition of Mexican propolis from Altiplano, Pacific Coast, Gulf and North zones is like to that reported from other temperate zones of the world. Meanwhile, the Peninsula of Yucatan zone differs to the rest of the country because of its tropical weather and flora. The most exploited species of honeybee in Mexico is the Apis mellifera, nevertheless the native honeybees are also cultured. Biological activity reported to date is anticancer, antiinflammatory, antidiabetic, antimicrobial and antiparasitic, which are the activities already documented for temperate propolis. Further research is needed on propolis from other states of the country, in order to accurately characterize and classify it, as well as the study of the geopropolis made by Meliponinos. Finally, all samples studied must be subjected to the criteria established in the Mexican regulation NOM-003-SAG/GAN-2017, for the purpose of making reliable comparisons.

\section{References}

1. Silva Carvalho, Baltazar F, Almeida Aguiar C (2015) Propolis: A Complex Natural Product with a Plethor a of Biological Activities. Evid Based Complement Alternat Med 2015:206439.

2. Burdock GA (1998) Review of the Biological Properties and Toxicity of Bee Propolis (Propolis). Food Chem Toxicol 36(4):347-363.

3. Castaldo S, Caspasso F (2002) Propolis, an old remedy used in modern medicine. Fitoterapia 73 Suppl. 1: S1-S6.

4. Pascoal A, Feás X, Dias T, Dias LG, Estevinho LM (2014) Chapter 13 The Role of Honey and Propolis in the Treatment of Infected Wounds. Kateryna Kon and Mahendra Rai (eds.), Microbiology for Surgical Infections, Academic Press Pp: 221-234.

5. Valadez Azúa R, Blanco Padilla A, Pérez Roldán G, Rodríguez Galicia B (2004) Retomando la apicultura del México Antiguo in Imagen Veterinaria. 4(2).

6. Villalobos Bucio CM, Navarro López FA, Martínez Jaime OA, Torres Morales JJ, García Aguilera E (2016) Producción de propóleo en campo, recolectado por las abejas productoras de miel (Apis mellifera). Investigación y Desarrollo en Ciencia y Tecnología de Alimentos 1(1):515-520.

7. Magaña Magaña M, Tavera Cortés ME, Salazar Barrientos LL, Sanginés García JR (2016) Productividad de la apicultura en México y su impacto sobre la rentabilidad. Revista Mexicana de Ciencias Agrícolas 7(5):11031115 .

8. Melliou E, Stratis E, Chinou I (2007) Volatile constituents of propolis from various regions of Greece-antimicrobial activity. Food Chemestry 103(2):375-380.

9. Gong S, Luo L, Gong W, Gao Y, Xie M (2012) Multivariate analyses of element concentrations revealed the groupings of propolis from different regions in China. Food Chemistry 134(1):583-588.

10. Kurek Gorecka A, Rezpecka Stojko A, Gorecki M, Stojko J, Sosada M, et al. (2014) Structure and antioxidant activity of polyphenols derived from propolis. Molecules 19(1):78-101.

11. Kasote DM, Pawar MV, Bhatia RS, Nandre VS, Gundu SS, et al. (2017) HPLC, NMR based chemical profiling and biological characterisation of Indian propolis. Fitoterapia 122:52-60. 
12. Woźniak M, Mrówczyńska L, Waśkiewicz A, Rogoziński T, Ratajczak (2019) Phenolic Profile and Antioxidant Activity of Propolis Extracts from Poland. Natural Product Communications 14(5):1-7.

13. Pobiega K, Kraśniewska K, Derewiaka D (2019) Comparison of the antimicrobial activity of propolis extracts obtained by means of various extraction methods. Journal of Food Science and Technology 56:53865395.

14. SAGARPA (2010) Situación actual y perspectiva de la apicultura en México. Claridades Agropecuarias 199:33-39.

15. Lima B, Tapia A, Luna L, Fabani MP, Schmeda Hirschmann G, et al. (2009) Main Flavonoids, DPPH Activity, and Metal Content Allow Determination of the Geographical Origin of Propolis from the Province of San Juan (Argentina). J Agric Food Chem 57(7):2691-2698.

16. Boisard S, Le Ray A, Gatto J, Aumond M, Blanchard P, et al. (2014). Chemical Composition, Antioxidant and Anti-AGEs Activities of a French Poplar Type Propolis. J Agric Food Chem 62(6):1344-1351.

17. Greenaway W, Scaysbrook T, Whatley FR (1987) The Analysis of Bud Exudate of Populus euramericana, and of Propolis, by Gas Chromatography-Mass Spectrometry. Proc R Soc Lond B 1:200-232.

18. Salatino A, Fernandes Silva CC, Righi AA, Salatino MLF (2011) Propolis research and the chemistry of plant products. Natural Products Reports 28(5):925-936.

19. Kumazawa S, Hamasaka T, Nakayama T (2004) Antioxidant activity of propolis of various geographic origins. Food Chemistry 84(3):329-339.

20. Boisard S, Tho Huyn TH, Escalante Erosa F, Hernández Chávez LI, Peña Rodríguez LM, et al. (2015) Richomme P Unusual chemical composition of a Mexican propolis collected in Quintana Roo. J Api Res 54 (Suppl. 4):350-357.

21. Ahn MR, Kunimasa K, Ohta T (2007) Suppression of tumor-induced angiogenesis by Brazilian propolis: major component artepillin C inhibits in vitro tube formation and endothelial cell proliferation. Cancer Lett 252(2):235-243.

22. Falçao SI, Vilas Boas M, Estevinho LM, Barros C, Domingues MRM, et al. (2010) Phenolic characterization of Northeast Portuguese propolis: usual and unusual compounds. Anal Bioanal Chem 396(2): 887-897.

23. Marghitas L, Laslo L, Dezmirean D, Moise A, Maghear O (2007) Total phenolics and antioxidant activity of Romanian propolis, International Conference Agricultural and Food Sciences, Progresses and Technologies, Sibiu.

24. Kosalec I, Bakmaz M, Pepelnjak S, Knežević S (2007) Quantitative analysis of the flavonoids in raw propolis from northern Croatia. Acta Pharm 54(1):65-72.

25. Popova MP, Bankova VS, Bogdanov S, Tsvetkova I, Naydenski C, et al. (2007) Chemical characteristics of poplar type propolis of different geographic origin. Apidologie 38:306-311.

26. Markham KR, Mitchel KA, Wilkins AL, Daldy JA, Lu Y (1996) HPLC and GC-MS identification of the major organic constituents in New Zealand propolis. Phytochemistry 42(1):205-211.

27. Volpi N, Bergonzini G (2006) Analysis of flavonoids from propolis by on-line HPLC- electrospray mass spectrometry. J Pharm Biomed Anal 42(3):354-361.

28. Bankova V, Bertelli D, Borba R, Conti BJ, Barbosa da Silva Cunha I, et al. (2016) Standard methods for Apis mellifera propolis research. Journal of Apicultural Research 58(2): 1:49.

29. Dzubak P, Hajduch M, Vydra D, Hustova A, Kvasnica M, et.al. (2006) Pharmacological activities of natural triterpenoids and their therapeutic implications. Nat Prod Rep 23(3): 394-411.

30. Rushdi AI, Adgaba N, Bayaqoob NI, Al Khazim A, Simoneit BI, et al. (2014) Characteristics and chemical compositions of propolis from Ethiopia. SpringerPlus 3:253.
31. Bankova V, Popova M, Trusheva B. (2014) Propolis volatile compounds: chemical diversity and biological activity: a review. Chem Cent J 8:28.

32. Herrera Lopez M, Rubio Hernández EI, Leyte Lugo MA, Schinkovitz A, Richomme P, et al. (2019) Botanical origin of triterpenoids from Yucatecan propolis. Phytochemistry Letters 29:25-29.

33. Karak P (2019) Biological activities of flavonoids: an overview. IJPSR 10(4):1567-1574

34. Rivero Cruz JF, Granados Pineda J, Pedraza Chaverri J, Pérez Rojas JM, Kumar Passari A, et al. (2020) Phytochemical Constituents, Antioxidant, Cytotoxic, and Antimicrobial Activities of the Ethanolic Extract of Mexican Brown Propolis. Antioxidants 9(1): E70.

35. Alday E, Valencia D, Carreño AL, Picerno P, Piccinelli AL, et al. (2015) Apoptotic induction by pinobanksin and some of its ester derivatives from Sonoran Propolis in a B-cell lymphoma cell line. Chem Biol Interact 242:35-44.

36. Li F, Awale S, Tezuka Y, Esumi H, Kadota S (2010) Study of the constituents of mexican propolis and their cytotoxic activity against PANC-1 human pancreatic cancer cells. J Nat Prod 73(4):623-627.

37. Hernández J, Goycoolea FM, Quintero J, Acosta A, Castañeda M, et al. (2007) Sonoran propolis: chemical composition and antiproliferative activity on cancer cell lines. Planta Med 73(14):1469-1474.

38. Chahar MK, Sharma N, Dobhal MP, Joshi YC (2011) Flavonoids: A versatile source of anticancer drugs. Pharmacogn Rev 5(9):1-12.

39. Guzmán Gutiérrez SL, Nieto Camacho A, Castillo Arellano JI, Huerta Salazar E, Hernández Pasteur G, et al. (2018) Mexican propolis: A source of antioxidants and anti-Inflammatory compounds, and isolation of a novel chalcone and e-caprolactone derivative. Molecules 23(Suppl. 2): 334 .

40. Rasul A, Millimouno FM, Ali Eltayb W, Ali M, Li J, etal. (2013) Pinocembrin: a novel natural compound with versatile pharmacological and biological activities. Biomed Res Int 2013: 379850.

41. Rivera Yáñez N, Rodríguez Canales M, Nieto Yáñez O, Jiménez Estrada M, Ibarra Barajas M, et al. (2018) Hypoglycaemic and antioxidant effects of propolis of Chihuahua in a model of experimental diabetes. Evid. Based Complement. Alternat Med 2018:4360356.

42. Granados Pineda J, Uribe Uribe N, García López P, Ramos Godinez MDP, Rivero Cruz JF, et al. (2018) Effect of Pinocembrin Isolated from Mexican Brown Propolis on Diabetic Nephropathy. Molecules 23(4): E852.

43. SameniHR, RamhormoziP, BandegiAR, TaherianAA,Mirmohammadkhani M, et al. (2016) Effects of ethanol extract of propolis on histopathological changes and anti-oxidant defense of kidney in rat model for type 1 diabetes mellitus. J Diabetes Investig 7(4):506-513

44. Priscilla DH, Roy D, Suresh A, Kumar V, Thirumurugan K (2014) Naringenin inhibits $\alpha$-glucosidase activity: A promising strategy for the regulation of postprandial hyperglycemia in high fat diet fed streptozotocin induced diabetic rats. Chem Biol Interact 210:77-85.

45. Mulvihill EE, Allister EM, Sutherland BG, Telford DE, Sawyez CG et al. (2009) Naringenin prevents dyslipidemia, apolipoprotein B overproduction, and hyperinsulinemia in LDL receptor-null mice with diet-induced insulin resistance. Diabetes 58(10):2198-2110.

46. Ahad A, Ganai AA, Mujeeb M, Siddiqui WA (2014) Chrysin, an antiinflammatory molecule, abrogates renal dysfunction in type 2 diabetic rats. Toxicol Appl Pharmacol 279(1):1-7

47. Velazquez C, Navarro M, Acosta A, Angulo A, Dominguez Z, et al. (2007) Antibacterial and free-radical scavenging activities of Sonoran propolis. J Appl Microbiol 103(5):1747-1756.

48. Navarro Navarro M, Ruiz Bustos P, Valencia D, Robles Zepeda R, Ruiz Bustos E, et al. (2013) Antibacterial activity of Sonoran propolis and some of its constituents against clinically significant Vibrio species. Foodborne Pathog Dis 10(2):150-158. 
49. Quintero Mora ML, Londoño Orozco A, Hernández Hernández F, Manzano Gayosso P, López Martínez R, et al. (2008) Efecto de extractos de propóleos mexicanos de Apis mellifera sobre el crecimiento in vitro de Candida albicans. Revista Iberoamericana de Micología 25(1):22-26.

50. Al-Ani I, Zimmermann S, Reichling J, Wink M (2018) Antimicrobial Activities of European Propolis Collected from Various Geographic Origins Alone and in Combination with Antibiotics. Medicines (Basel) $5(1): 2$.

51. Cushnie TP, Lamb AJ (2005) Antimicrobial activity of flavonoids. Int J Antimicrob Agents 26(5):343-356.

52. Cushnie TP, Lamb AJ (2011) Recent advances in understanding the antibacterial properties of flavonoids. Int J Antimicrob Agents 38(2):99107.

53. Alday Provencio S, Diaz G, Rascon L, Quintero J, Alday E, et al. (2015) Sonoran propolis and some of its chemical constituents inhibit in vitro growth of Giardia lamblia trophozoites. Planta Med 81(9):742-747.

54. Alotaibi A, Ebiloma GU, Williams R, Alenezi S, Donachie A, et.al. (2019) European propolis is highly active against trypanosomatids including Crithidia fasciculata. Sci Rep 9:1-10

55. Bradbear N (2009) Bees and their roles in forest livelihoods. A guide to services provided by bees and the sustainable harvesting, processing and marketing of their products. Food and Agriculture Organization of the United Nations. Rome, Italy.

56. Ayala R (2013) Abejas nativas de Mexico, La importancia de su conservacion. Ciencia y Desarrollo 36:8-13.

57. Quezada Euan, José Javier, Parra Guiomar, Maues, Marcia, Roubik David, et al. (2018) The economic and cultural values of stingless bees (Hymenoptera: Meliponini) among ethnic groups of tropical America. Sociobiology 65(4):534-557.

58. Ortrud Monika Barth, Cynthia Fernandes Pinto Da Luz (2003) Palynological analysis of Brazilian geopropolis sediments. Grana 42(2):121-127.

59. Dos Santos CM, Campos JF, Dos Santos HF, Balestieri JBP, Silva DB, et al. (2017) Chemical Composition and Pharmacological Effects of Geopropolis Produced by Melipona quadrifasciata anthidioides. Oxidative Medicine and Cellular Longevity 2017:8320804.
60. Dutra RP, Nogueira AMC, Marques RRO, Costa MCP, Ribeiro MNS (2008) Avaliação farmacognóstica de geoprópolis de Melipona fasciculata Smith da Baixada maranhense, Brasil. Rev Bras Farmacogn 18(4): 557-562.

61. Cunha MG, Franchin M, Galvão LCDC, Bruno BuenoSilva, Masaharu Ikegaki, et al. (2013) Apolar bioactive fraction of Melipona scutellaris geopropolis on Streptococcus mutans biofilm. Evidence Based Complementary and Alternative Medicine 2013:ID 256287.

62. Yildiz O, Karahalil F, Can Z, Sahin H, Kolayli S (2013) Total monoamine oxidase (MAO) inhibition by chestnut honey, pollen and propolis. J Enzyme Inhib Med Chem 29(5): 690-694.

63. Liberio SA, Pereira ALA, Dutra RP, Aramys S Reis, Maria José A M Araújo, et al. (2011) Antimicrobial activity against oral pathogens and immunomodulatory effects and toxicity of geopropolis produced by the stingless bee Melipona fasciculata Smith. BMC Complementary Altern Med 11: 108.

64. De Souza SA, da Silva TMG, da Silva EMS, Camara CA, Silva TMS (2018) Characterisation of phenolic compounds by UPLC-QTOF-MS/MS of geopropolis from the stingless bee Melipona subnitida (jandaíra). Phytochem Anal 29(6):549-558.

65. Dutra RP, Abreu BVB, Cunha MS, Marisa Cristina Aranha Batista, Luce Maria Brandão Torres, et al. (2014) Phenolic acids, hydrolyzable tannins, and antioxidant activity of geopropolis from the stingless bee Melipona fasciculata Smith. J Agric Food Chem. 62(12):2549-2557.

66. Yam Puc A, Santana Hernández AA, Yah Nahuat PN, Ramón Sierra JM, Cáceres Farfán MR, et al. (2019) Pentacyclic triterpenes and other constituents in propolis extract from Melipona beecheii collected in Yucatan, México. Revista Brasileira de Farmacognosia 29(3):358-363.

67. Pino JA, Marbot R, Delgado A, Zumarraga C, Sauri E (2006) Volatile constituents of propolis from honey bees and stingless bees from Yucatan. J Essent Oil Res 18(1):53-56.

68. Torres González A, López Rivera P, Duarte Lisci G, López Ramírez A Correa Benítez A, et al. (2016) Analysis of volatile components from Melipona beecheii geopropolis from Southeast Mexico by headspace solid-phase microextraction. Nat Prod Res 30(2):237-240.

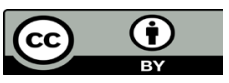

This work is licensed under Creative Commons Attribution 4.0 License

To Submit Your Article Click Here: Submit Artic

DOI: 10.32474/LOJPCR.2020.02.000137

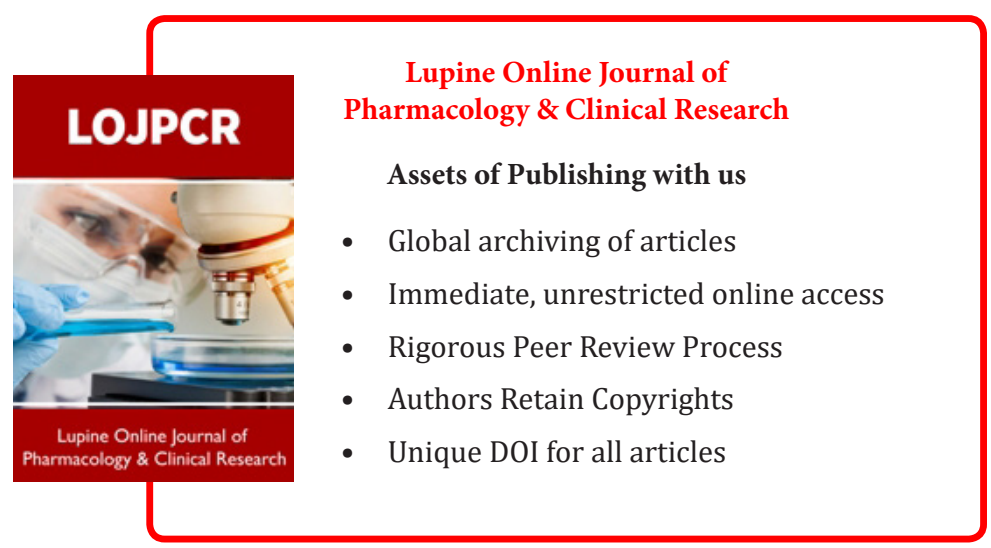

